\title{
trabalhonecessário
}

iss $\mathrm{n}: 1808-799 \mathrm{X}$

ano 1 - número 1 - 2003

\section{PROPOSTAS PARA UM TRABALHO COLETIVO DE RENOVAÇÃO PROGRAMÁTICA*}

François Chesnais

A finalidade do texto é apresentar um esboço do que pode ser - reformulado, enriquecido e desenvolvido coletivamente - a base de um "projeto de investigação e elaboração políticas iluminado pelo objetivo de transformação socialista da sociedade". Esse projeto seria levado adiante conjuntamente com aqueles que, dentro e fora de Carré Rouge, reconheçam sua necessidade e compartilhem (em linhas gerais, é claro) da problemática da partida. As revistas que desejarem colaborar no projeto poderiam contribuir no trabalho de publicação. $O$ texto tenta dar elementos que também poderiam estimular a que militantes sindicais não-organizados politicamente se unam ao trabalho.

Durante os últimos anos, em diferentes ambientes se produziu - e foi publicado em várias revistas - bastante material teórico novo, que pode alimentar um "projeto de investigação e elaboração políticas". Mas, com poucas exceções, essa produção teórica não foi explicitamente "iluminada pelo objetivo de transformação socialista da sociedade". O que pode distinguir a nossa proposta é a vontade de continuar trabalhando com essa perspectiva, a despeito do curso adotado pela história do século XX e do começo do século XXI. Isto multiplica a vontade de colaborar com todos os que, em diferente medida, se identifiquem com a análise da segunda e da terceira partes do texto.

\section{PRIMEIRA PARTE}




\section{Razão de ser de Carré Rouge}

Publicar Carré Rouge não é um fim em si mesmo. Carrè Rouge não tem vocação para se perpertuar se sua razão de ser não for consolidada qualitativamente. É certo que a revista permite a uns poucos militantes aclarar e apresentar regularmente sua apreciação da situação política francesa. Também são publicados artigos de reflexão teórica sobre questões chaves da luta de classes e do pensamento revolucionário, relacionadas, principalmente, à herança marxista. Mas isto não é justificativa suficiente para a existência de Carrè Rouge. Não há uma verdadeira necessidade de mais uma revista política.

Em 1995, alguns militantes [veteranos] da Organização Comunista InternacionalistaPartido Comunista Internacionalista[1] (mais exatamente éramos seis) nos encontramos e fundamos Carré Rouge. Desejávamos fazer um balanço e recuperar o gosto pela ação e pela discussão política. Rapidamente tentamos obter a colaboração de militantes provenientes de outros horizontes. Assim, acolhemos camaradas de Voz dos Trabalhadores e militantes da Liga Comunista Revolucionária, da Esquerda Comunista do Partido Comunista Francês, e mais tarde de A Comuna e da Esquerda Revolucionária, que participaram de reuniões e escreveram segundo o ritmo das discussões e dos acontecimentos da vida política francesa. Com uma clareza crescente sobre este enfoque, a redação de Carré Rouge buscou fazer da revista um instrumento para outros. Outros que são todos os que continuam considerando que "o socialismo é a única meta que uma inteligência contemporânea pode se propor". Esta é a citação de Siniavsky que figura na capa da revista desde seu lançamento.[2] Agora, com relações a definir com outras correntes, coletivos e militantes individuais, é possível que Carré Rouge encontre uma razão de ser para continuar reunindo-se e aparecendo, convertendo-se, com outras revistas, num dos suportes de um trabalho coletivo, o que chamo de maneira imprópria [tosca e breve] "projeto de investigação e de elaboração políticas iluminado pelo objetivo de transformação socialista da sociedade". O propósito seria superar as omissões e a paralisação de balanços incompletos e nos permitir definitivamente sair do empirismo total que, por agora, caracteriza nosso trabalho político.

\section{SEGUNDA PARTE}

\section{Um vazio programático e estratégico}

Por que este "projeto de investigação"? Porque hoje estamos desprovidos de uma orientação política digna desse nome (em outra época teríamos dito diretamente de um programa), fundada na luta pela transformação socialista da sociedade e ao mesmo tempo enraizada numa análise dos processos sociais e políticos contemporâneos tal como são realmente (não ficticiamente) no início do século XXI. Para dizer claramente, os militantes que determinam sua atividade política e/ou sindical quotidiana em função do caráter irredutível do antagonismo entre o capital (os proprietários dos meios de produção e de comunicação, isto é, dos meios de vida da sociedade) e aqueles que vendem ou tentam 
vender sua força de trabalho (o imenso exército industrial de reserva que o capital constituiu em escala mundial), "navegam politicamente sem bússola". Isto é ainda mais grave porque a situação política contém, parece-me, muitos elementos de uma "brusca reviravolta". Esta foi sempre uma característica da época imperialista, mas todo um período da luta de classes mundial terminou em 1989-1991 sem que disto avaliássemos as conseqüências. A "brusca reviravolta" que nos espera num prazo mais ou menos longo não se apoiará nos dados e "parâmetros" políticos dos anos 1930, nem nos de 1960-1970. Funcionamos com referências programáticas que devem ser reconstruídas dos pés à cabeça, o que supõe acabar com a fetichização dos escritos de nossos antecessores.

Cada militante (ou cada grupo de militantes com afinidades políticas) declinará esta afirmação com a linguagem de sua tradição política e com referência à sua própria experiência. Nesta seção, o farei a partir da experiência e na linguagem do trotskismo. Os militantes de origem comunista "ortodoxa", surgidos do molde caracterizado por nós como stalinismo[3] ou aqueles da variante maoísta dirão, se quiserem, como vêem essa questão. O mesmo vale para os militantes da família do anarquismo e do anarco-sindicalismo.

Ninguém pode faze-lo em seu lugar.

Na Carré Rouge temos a convicção comum de que nenhuma corrente política ou sindical séria, que tenha como meta destruir o capitalismo ombro a ombro com milhões de mulheres e homens cuja adesão deve ser obtida (e não a construção de uma seita ou de uma igreja milenarista), pode continuar dizendo-se "armada com um programa". Nenhuma corrente política utiliza hoje uma orientação que não repouse ou em um ato de fé (apoiado por documentos historicamente datados, ossificados ou, o que é pior, fetichizadas) ou num empirismo total. A falta de "programa", no sentido de uma orientação estratégica (os objetivos, os meios) que responda às questões chaves da ação política com a perspectiva socialista é um dos traços constitutivos da atual situação política. De fato, a extrema debilidade ou o vazio teórico é um traço constitutivo da situação política na França, na Europa e em todos os continentes.

Durante toda um época os trabalhadores influenciados pelos PCs sabiam ou pressentiam que a URSS no era o paraíso socialista, mas esperavam que uma reforma democrática do sistema desse à Revolução de Outubro uma segunda oportunidade, uma nova juventude. Os trabalhadores influenciados pela IV Internacional e os militantes dos distintos agrupamentos, além das diferenças nascidas de múltiplas cisões, combatiam por uma revolução mundial da qual a revolução política anti-stalinista era parte constitutiva.

A queda do Muro de Berlim e o desaparecimento da URSS mudaram tudo. Mas não em benefício do socialismo, mas da contra-revolução burocrática e imperialista que se deu. Milhões de assalariados e de militantes ficaram desnorteados. Têm o sentimento de que não há futuro. A esperança aberta em 1917 está morta. O capitalismo é apresentado aos assalariados de todo o mundo como uma realidade insuperável, sem que a tal pretensão 
possa se contrapor uma perspectiva estratégica. Evidentemente, este fato pesa no conjunto da luta de classes internacional. Já não há um projeto de futuro emancipador afirmado teórica e politicamente. É necessário reconstruí-lo. Sem esperar um acontecimento salvador, há que se comprometer com modéstia e ambição num trabalho coletivo de investigação e debate sem tabus. É necessário dedicar-se à reconstrução de um futuro socialista do qual possam se apoderar as forças vivias da sociedade.

\section{A QUE QUESTÕES RESPONDEM OS PROGRAMAS?}

Tratando-se da passagem de um modo de produção e de uma forma de propriedade para outro modo de produção e formas de propriedade totalmente diferentes, o programa revolucionário, do Manifesto do partido comunista (1847) ao Programa de transição (1938), passando pelos documentos programáticos da Internacional Comunista (1919-1923), incluiu quase que invariavelmente, no nosso entender, os seguintes pontos:

- as razões pelas quais as relações de propriedade e de produção capitalistas devem ser substituídas, isto é, destruídas e não reformadas;

- a designação da ou das classes possuidoras simultaneamente com capacidade social, à força organizativa e sobretudo às motivações suficientemente para comprometer-se na luta condizente com essa transformação;

- a definição dos processos econômicos fundamentais e dos pontos políticos em que podia apoiar-se o projeto de transformação das relações de propriedade e de produção e a ação para tal dessa ou dessas classes;

- a definição de tipos de crises políticas e sociais suscetíveis de gerar as condições concretas que sobre-determinando esses processos fundamentais abrirão a possibilidade de se empreender a "conquista do poder", ponto de partida da transformação das relações de propriedade e de produção;

- a definição das formas de organização e dos organismos a serem construídos para deslocar a classe dominante do poder;

- finalmente, a definição das formas de organização do poder que deverão ser construídas para atravessar as primeiras etapas da transformação das relações de propriedade e de todas relações sociais.

Nenhuma das respostas dadas a estes pontos, desde o Manifesto de 1847, pode ser considerada como imutável, como se fossem definições dadas de uma vez para sempre, nem sequer em suas "grandes linhas". Todas são, em graus diversos, mas sempre importantes, historicamente determinadas. $O$ valor das posições tomadas pelos grandes teóricos e práticos da revolução assenta-se sobretudo em seu método, nos caminhos que seguiram. Pensar o contrário não só seria sair do marco do marxismo, que insistiu mais do que qualquer outro corpus teórico na historicidade da ação humana (e, por isto, do mundo "natural" também). Significaria sair, totalmente, da racionalidade elementar. Temos contribuído bastante para isso, no entanto, durante grande parte de nossa vida militante. Já é tempo de não mais faze-lo. É o momento, o grande momento de voltarmos a ser marxistas.

A OSSIFICAÇÃO PROGRAMÁTICA DO PONTO DE VISTA TROTSKISTA 
Em nossa tradição política, considerou-se o Programa de transição como fonte da maior parte das respostas aos pontos indicados, complementado com as Resoluções dos quatro primeiros congressos da Internacional Comunista e alguns trabalhos políticos chave, de Trotsky, em particular as teses de $A$ revolução permanente e de $A$ revolução traída. Segundo a experiência que vivemos, muito tempo depois dessas obras terem sido escritas e em contextos políticos já muito modificados, receberam o status de textos programáticos, inquestionáveis ou até mesmo intocáveis, como se fossem, dizendo mais claramente, as "tábuas da lei". Isso apesar de que, como está dito explicitamente no texto de 1938, o Programa de transição foi redigido em relação a uma série de acontecimentos e experiências políticas muito específicas e para um período histórico determinado. A experiência nos indica que inclusive no período em que o Programa de transição mais ou menos respondia às questões assinaladas, teriam sido necessárias reformulações que 0 assassinato de Trotsky cortou bruscamente.[4] O que em todo caso é seguro é que o período para o qual o Programa de transição dava respostas está acabado, definitivamente acabado.

Aqueles que negam isso pertencem, grosso modo, a três categorias. A primeira é a dos falsários políticos que se protegem por trás de um programa declarado inalterável, ao qual só um pequeno círculo de iniciados (às vezes só um) erigidos como uma espécie de "sumos sacerdotes" pode consentir em propor as "leituras" ou "interpretações" de tipo talmúdico com relação a tal ou qual situação concreta. $O$ "respeito ao programa" se converte então não só numa celebração "para os dias de festa", mas na fachada por trás da qual esses dirigentes estão livres para seguir uma política cotidiana de adaptações e às vezes traições. A segunda categoria é a dos crentes apegados a textos políticos que convertem em fetiches, em textos religiosos. Baseados nisso, desenvolvem uma ação militante devota, mas que nada tem a ver com a política. Às vezes ambos os tipos coabitam no seio de uma mesma organização, mas outros grupos reúnem de maneira homogênea, militantes da segunda categoria. Esses grupos se transformam em refúgios diante da realidade, em bunkers rodeados por um mundo hostil. Não são contudo "remansos de paz", pois sua evolução os transforma em espécies de manicômios onde se digladiam mutuamente em nome da ortodoxia que é necessário preservar ou pela direção do grupo que é preciso derrubar.[5] A terceira categoria é formada por militantes que estão conscientes de agir não tendo um programa político no verdadeiro sentido do termo, mas que dizem que as tarefas urgentes são prioritárias, que uma refundação programática pode esperar. Carré Rouge corresponde em grande medida a esta definição,[6] embora tenhamos finalmente tomado consciência de que chegou o grande momento de remediála.

\section{O CARÁTER HISTORICAMENTE DETERMINADO DO PROGRAMA DE 1938}

O período para o qual foi escrito o Programa de transição está superado, do mesmo modo que aquele em que foram redigidos os textos adotados pelos quatro primeiros congressos 
da Internacional Comunista. A lista de fatos que sustentam esta afirmação é longa, e o objeto deste trabalho não é tanto colocá-los de maneira exaustiva, mas começar a enunciar pelo menos os "cabeçalhos" dos blocos temáticos que deveriam ser trabalhados coletivamente numa perspectiva de reconstrução. Para ir ao essencial, limitar-nos-emos aos elementos que se seguem.

Uma das pedras angulares ou a peça mestra do Programa de Transição é o conjunto de proposições segundo as quais algumas das conquistas decisivas da Revolução de Outubro (a propriedade estatal dos meios de produção, o monopólio do comercio exterior, etc.) foram enfraquecidas mas não destruídas pela ditadura stalinista; que sob a ação do proletariado uma corrente progressista autenticamente proletária podia ainda desprenderse da burocracia (como a "tendência Reiss"), de tal modo que uma "revolução política" podia derrotar a burocracia e transformar a URSS novamente na caldeira da revolução mundial. Estas questões são a pedra angular do programa de 1938: junto com a caracterização da crise do capitalismo, são constitutivas dos processos políticos fundamentais nos quais podia apoiar-se a classe operária para a destruição do capitalismo. Independentemente das políticas de adaptação aos aparatos stalinistas que essas propostas suscitaram em todos os países onde existia um PC forte, no que diz respeito à URSS esse conjunto de proposições se foi debilitando cada vez mais ao longo da segunda metade do século XX. A revolução Húngara de 1956, a "primavera de Praga" e as reiteradas lutas da classe operária polonesa, tanto quanto as rupturas dos aparatos dos PCs em países expostos à irrupção dos operários e da juventude, forneceram-lhe um principio de materialização, mas num contexto de forte interconexão com a questão nacional e com a luta pela independência. Na URSS, contudo, não houve nenhuma ruptura no interior do aparato que abrisse uma via à classe operária dos estados da federação soviética. Assim, o punho de ferro da dominação burocrática e da repressão policial mataram no nascedouro as mobilizações operárias toda vez que se produzia um levante. Mais tarde, a queda do muro e o desmoronamento da URSS em proveito da restauração capitalista tornaram definitivamente obsoletas as proposições essenciais do programa de 1938.

Não foram afetadas apenas as partes relativas à "revolução política, mas todo o programa, já que tinha sido construído sobre idéia força da revolução de outubro como "primeiro elo da revolução mundial". Os que inventam razões para manter essa perspectiva vivem fora do mundo real onde devemos lutar. $E$ isto não diz respeito apenas aos trotskistas, mas também a todas a variantes de "nostálgicos da URSS", filiados ou ex-filiados ao PCF.

Além disso, existem razões adicionais. A redação do Programa de 1938 está marcada pelo formidável impacto da Revolução Espanhola e da greve geral francesa de junho de 1936. Estes fatos coloriram fortemente as hipóteses do Programa de Transição sobre a predisposição, basicamente revolucionaria, do proletariado dos países capitalistas e, correlatamente, sobre o acirramento do seu antagonismo potencial com os partidos e 
direções sindicais social-democratas e ou stalinistas. A partir de 1948 isso mal se verificou, no melhor dos casos, de forma episódica. Tampouco se verificaram, em países de capitalismo avançado, as hipóteses sobre a possibilidade de que dirigentes socialdemocratas e/ou stalinistas, em condições excepcionais, viessem a se comprometer com o caminho de ruptura com a burguesia. Inclusive antes da virada "social-liberal" dos dirigentes social-democratas, Largo Caballero[i] teve poucos êmulos em suas fileiras.

A profunda crise econômica dos anos 30 afetou com força, como é lógico, o juízo do Programa de Transição quanto à capacidade do capitalismo para fornecer aos aparatos sindicais e políticos "grão para moer" (esclarecedora expressão do chefe sindical André Bergeron da Force Ouvrière) em quantidade suficiente para permitir-Ihes conter a ação da classe operária. Em 1938, os mecanismos de acumulação capitalista estavam efetivamente falidos. Os historiadores têm documentado amplamente que, para retomar a acumulação, a economia norte-americana teve de esperar até 1942. isto é, até Pearl Harbour e o inicio do regime de plena produção armamentista. Em 1938 era correto escrever que a "política do New Deal não oferecia nenhuma saída para o impasse econômico", porem isto apenas salienta a presença de elementos conjunturais no Programa de Transição, aspecto este do qual nunca foram tirados ensinamentos metodológicos. A partir dos anos 60 era absurdo apegar-se a tais fórmulas para caracterizar a situação das economias capitalistas avançadas. Do mesmo modo, era falso deixar-se influenciar pelas teses do stalinismo modernista italiano, referidas ao "neocapitalismo".

Escrito em 1938, quando era "meia-noite no século", o Programa de Transição representava um ato de resistência ao stalinismo e ao imperialismo de importância inestimável, que incluía uma forte dose de messianismo político. A proposição "as leis da historia são mais poderosas que os aparatos burocráticos" é um dos exemplos mais dramáticos que, no caso da OCl-PCl se transformou numa espécie de fórmula mágica para os dias aziagos. Daí surge a sobre-estimação do nível de radicalização das situações políticas, o que provavelmente é um dos traços mais difundidos entre os militantes formados no trotskismo da nossa corrente.

A partir da recuperação capitalista dos anos 1950-60, a tendência para a "superestimação" esteve acompanhada por uma subestimação da força dos mecanismos de dominação capitalista derivados do poder inerente ao fetichismo da mercadoria e a fascinação que suscita, como deslumbramento pelo acesso à propriedade individual. Isto permite entender porque, malgrado o enfraquecimento constante dos aparatos stalinista e social-democrata, a classe operária nunca os varreu completamente. Inclusive quando tais aparatos tornaram-se a sombra do que tinham sido, a classe operária nunca se lançou realmente para eliminá-los. Nuca se viu nos países capitalistas avançados uma fúria contra os aparatos equivalente a de Budapeste ou Praga. Pelo contrário, alguns segmentos de operários, professores e empregados continuaram fornecendo-lhes, durante longo tempo, 
pontos de apoio necessários para a sua sobrevivência, e permitiram ainda que organizações sindicais de essência burguesa, como a CFDT, ganhassem influência. Isto nada tem a ver com a força intrínseca dos aparatos que são muito fracos em numerosos países, a começar pela França, onde dependem do financiamento do estado e da patronal, mas tem muito a ver com alguns mecanismos da dominação capitalista que não tinham grande peso na época do Programa de 1938.

Mas essa explicação também é parcial e incompleta. Nos países industrializados, apesar das tendências ao bonapartismo, o exercício das liberdades democráticas, a democracia representativa e o sufrágio universal também permitiram aos capitalistas (auxiliados pelos aparatos contra-revolucionários) desviar e amortecer continuamente os choques da luta de classes. A utilização e a instrumentalização das eleições pelo PC e o PS sempre permitiu ao sistema desviar as massas da política, entendida como combate pelo exercício efetivo do poder. Estes partidos seguiram e geralmente aplicaram de modo muito consciente um processo de autonomização análogo ao do Estado. Organizaram entre os trabalhadores a delegação das gestões dos seus interesses a representantes quase inamovíveis (a classe política, os profissionais da política). A luta revolucionária implica incorporar estes dados. Sem uma reflexão estratégica sobre a relação entre a luta de classes direta e a participação eleitoral, esta situação ameaça repetir-se ao infinito. A questão do mandato político, do seu controle, do seu respeito, da revogação dos eleitos, em síntese, da democracia representativa sob controle permanente dos mandantes, envolve a de autoorganização das massas.

\section{SOBRE A GRANDE ASCENSÃO DOS ANOS 1960-1970}

Entre 1968 e 1975-78 (o final é mais difícil de datar com precisão do que o inicio) o Programa de Transição ou, mais exatamente, algumas de suas partes, atingiram seu mais elevado poder orientador da ação política revolucionaria. Durante uma década, aproximadamente, "massas de milhões de homens", operários, estudantes, mulheres desenvolveram lutas radicais numa série de países, começando a ameaçar as bases da ordem estabelecida. Nesses anos houve, inquestionavelmente, uma "crise conjunta de dominação da burguesia e da burocracia stalinista", fundada em e interligada com uma conjugação particular de muitos acontecimentos e processos de grande amplitude.

Houve, em primeiro lugar, a partir de Berlin (1953) e da Hungria e Polônia (1956) novas (e derradeiras) manifestações de um movimento para a revolução política em países de "democracia popular" sob dominação stalinista. No início do período, na Checoslovaquia, a implosão do aparato satélite stalinista abriu caminho para um movimento de operários, intelectuais e estudantes. No final do período foi a Polônia, com as grandes greves nos portos do Báltico e a fundação de Solidárnost, primeiro influenciada e logo a seguir controlada totalmente pela Igreja. Em 1968-69 também entraram em ação milhões de operários na França e na Itália, cientes das suas reivindicações e adqüirindo consciência da força decorrente da sua concentração nas grandes fábricas. A força dos operários 
ingleses para provocar a queda do governo Heath foi outra manifestação da mesma capacidade de impor reivindicações mais elevadas a governos formados por partidos tradicionais da burguesia ou forçá-los a um completo recuo. Temos ainda o caso Vietnam, isto é, a interação - com uma força muito especial nos EE.UU - do combate dos operários e camponeses de um país semicolonial (dirigidos pelo último aparato comunista que teve uma conduta tal que pôde tornar-se objeto de forte mistificação) com o movimento social da classe operária e sobretudo da juventude (nos EE.UU. apenas essa última) dos países avançados. Este interagir atingiu um nível de radicalização suficiente para gerar as condições políticas internas que levaram os EE.UU. a sofrer determinada forma de derrota política e militar. Finalmente, entre 1975 e 1978, de Portugal ao Irã e depois à Nicarágua, houve crises revolucionárias oriundas (sob diferentes configurações) da luta pela libertação nacional em estados coloniais e semicoloniais. Neste sentido, importa salientar que foi "a revolução dos capitães", após anos de guerra colonial, a que abriu a brecha pela qual a classe operária portuguesa se lançou. A revolução portuguesa não se originou no interior das relações capital/trabalho.

Esta combinação particular de processos e acontecimentos permitiu que a luta de classes atingisse uma intensidade desconhecida desde 1948. Esta "sobre-determinação" é a responsável pelo caráter excepcional da situação. No entanto, apesar disso, a "crise das formas de dominação política da burguesia e da burocracia"[7], real durante um curto lapso de tempo, não foi seguida em nenhum país por eventos de natureza essencialmente revolucionária que varressem tudo a sua passagem. Não houve tentativas operárias de criar formas de organização[8] a partir das quais se apresentasse como uma classe disposta a construir uma nova forma de poder, para criar junto com a juventude - que estava pronta, incluindo segmentos de origem burguesa - o ponto de partida para desmontar as formas de propriedade capitalista.

Explicando aos seus militantes que não deviam "lançar-se a aventuras", as direções do PCF e da CGT na França e do PCI e CGIL, na Itália, conseguiram barrar um movimento profundo, mantendo, uma vez mais, a aposta burguesa. Todavia garantiram, ainda que "deplorando-a", a intervenção dos tanques em Praga; o aval à política de Brejnev e o isolamento do movimento na Checoslovaquia. Não foram solapados pelo movimento de massas. É forçoso constatar que o comportamento da classe operária da Europa Ocidental não esteve dominado (ainda que, certamente, existiram exceções setoriais) pelo sentimento de que fosse indispensável acabar com a exploração e, por conseguinte, com a propriedade privada dos meios de produção, e que as condições políticas para faze-lo estavam aparecendo. Como explicar isto? As sérias incertezas, incluso não explicitadas, sobre o "modelo de socialismo" que nesse momento viria a substituir o capitalismo, seguramente contribuíram para isso. Mas também contribuíram as ilusões, ainda muito fortes, sobre um futuro condigno para eles e para os seus filhos nos moldes do capitalismo. Excetuando casos muito restritos, repetimos, a classe operária não contestou 
os aparatos de modo frontal. Na França foram aceitas, sem provocar revoltas de massas, as políticas de "repartição do bolo" através das reivindicações salariais.[9]

Pode-se estimar que as organizações trotskistas foram tributárias dessas situações. Estivemos tão carentes de apoio da classe operária como ela de nós.

Sem uma atuação vigorosa da classe operária parece pouco provável que, considerando seu escasso nível de experiência, as organizações trotskistas pudessem dar, por si mesmas, o salto político qualitativo para a formação de verdadeiros partidos. No entanto, não era em absoluto inevitável retomar ou aprofundar uma trajetória de adaptação aos aparatos, cujas conseqüências somente se manifestaram nos anos de Mitterand.

Após a fase de acirrada e variada luta de classes e de crise política de dominação em numerosos paises, o refluxo que a sucede inaugura algo muito diferente de uma ressaca clássica (como, por exemplo, a ocorrida na Europa Ocidental, a partir de 1948). As derrotas - pois, de fato, foram autênticas derrotas, ainda que naquela altura recusássemos aceitá-lo - não abriram simplesmente, o caminho para um retrocesso, inclusive muito profundo, da luta de classes: puseram fim a um longo período da luta de classes[10]. Esta afirmação tem um alcance geral que ultrapassa o debate sobre o caráter historicamente determinado do Programa de Transição. Acredito que ninguém poderá questioná-lo, mesmo que se recuse a tirar as conclusões correspondentes.

A mudança de período tornou-se de imediato evidente nos países de Leste. O triunfo da contra-revolução burocrática na Checoslovaquia e na Polônia traduziu a ausência de condições constitutivas da revolução política da URSS. A tragédia dos tanques soviéticos em Praga teve conseqüências irreversíveis, em particular por ter sido acompanhada anos mais tarde, pelo golpe de estado de Jaruzelski, em Varsóvia. A URSS afundou na "estagnação" brejnevista antes se lançar a uma guerra sem saída no Afeganistão e, por último, dar vida aceleradamente a uma versão radical da "tendência Boutenko", isto é, de uma ala (amplamente majoritária) da burocracia selvagem e reacionária, ávida por restaurar a propriedade privada dos meios de produção em beneficio próprio. Um processo análogo foi desenvolvido na lugoslávia, de modo que a sua implosão, em 1991, acompanharia a da URSS.

Nos países capitalistas o fim de toda uma fase da luta de classes está relacionado com a somatória de derrotas operárias - sérias, porem "clássicas", isto é, com precedentes históricos-; com mutações técnicas como as que o capitalismo experimenta somente em intervalos muito dilatados. Por isso, as derrotas sofridas por importantes setores da classe operária de Europa Ocidental (a quente, como a dos mineiros e portuários britânicos, ou a frio, como a dos siderúrgicos de Lorena (França) sob o governo a União da Esquerda) apresentam a particularidade, não de terem gerado as clássicas ondas de demissões em massa, mas a liquidação de indústrias completas, com a subseqüente eliminação de segmentos completos da classe operaria. Inclusive em indústrias que não tiveram um 
destino tão radical iniciou-se nos anos 1980 um processo, ainda em andamento, de "desconcentração" e de fragmentação da organização produtiva, assim como também do proletariado industrial concentrado que protagonizou a luta de classes ao longo do século XX e de forma espetacular nos anos 1968-1975.

É inaceitável desconsiderar a capacidade do capitalismo para fazer da tecnologia uma arma e recusar-se a admitir (como fazem muitos militantes) que entanto elas persistirem as relações capital/trabalho permitirão à burguesia organizar o trabalho em função das possibilidades oferecidas pela técnica. As técnicas surgidas nos anos l890-1900 exigiam a concentração de grandes massas operárias; no entanto, as que aparecem e proliferam rapidamente no século seguinte permitem produzir organizando a fragmentação e a divisão do proletariado. Não existe um "adeus ao proletariado", antes pelo contrário, aproveitando uma favorável correlação de forças, a burguesia recria enorme contingente de mulheres e homens forçados a vender sua força de trabalho nas piores condições, à margem de qualquer convenção coletiva ou legislação trabalhista efetiva[11]. Não é "trair a classe operária" constatar, para poder colocar melhor as coisas mais adiante, que uma determinada configuração da classe operária, aquela que prevalecia na época de redação do Programa de transição, pertence ao passado10.

Existem outras dimensões do final deste período da luta de classes que estão a exigir novas análises. Uma das mais importantes é o da incorporação de estados ex-coloniais o semicoloniais numa fase histórica da luta de classes que não é mais a de luta pela independência nacional, que foi um dos elementos constitutivos do período encerrado. $E$ isto exigirá uma reflexão sobre as novas bases da conexão entre a luta de classes dos países capitalistas avançados, partes integrantes do imperialismo, e os países capitalistas dominados.

\section{AS "FORMAS TRADICIONAIS DE ORGANIZAÇÃO DA CLASSE OPERARIA"}

No Carré Rouge continuamos utilizando a frase "formas de organização tradicionais" para designar sindicatos e partidos que foram construídos pela classe operária entre 1880 e 1920. Em particular, designamos ao Partido Socialista e ao Partido Comunista Francês com a expressão "partidos tradicionais" ou "partidos operário-burgueses". Fazemo-lo com constrangimento crescente, pois além das mudanças tecnológicas que experimentaram e de sua política ativa destinada a submeter à sociedade francesa ao "capitalismo internacional dos fundos de pensão", são resíduos remanescentes de um período ultrapassado da luta de classes. Os dirigentes do PS traduzem de forma coerente essa realidade ao querer ir abertamente na direção de um tipo de partido "democrata", segundo o figurino norte-americano. O que os freia é o medo a abrir espaço para a formação de novos partidos que sejam representantes autênticos dos interesses dos assalariados e oprimidos.

No PCF, o grupo dirigente que rodeia Hue e Gayssot somente suspendeu sua empreitada 
para dissolver o próprio nome do partido pelo temor a que o vazio deixado pela desaparição da sigla permitisse a outros construir mais facilmente um partido com um programa anticapitalista e antiimperialista. E são as dificuldades que vem demonstrando os opositores de Hue e Gayssot para analisar a situação atual, para reconhecer a função desempenhada pelo PCF no enquadramento e no desvio do movimento da classe operária e da juventude e para formular uma alternativa programática clara as que alimentam essa longa agonia que pesa fortemente na situação política.

Na Confederação Geral do Trabalho, na Força Operária e também nos Sindicatos Unitários e Democráticos de natureza e consistência indefinidas, a questão está colocada de modo diferente. É necessário reescrever as condições do combate sindical. Isto implicará uma reafirmação clara, sem qualquer ambigüidade, do antagonismo irredutível entre o capital, seu Estado e os governos que Ihe servem, de um lado, e de outro os homens e mulheres obrigados a vender sua força de trabalho nas condições impostas pela propriedade dos meios de produção e a rentabilização dos ativos financeiros. Esta tarefa é hoje mais difícil do que era antes dos progressos realizados pelo capitalismo para impor a competitividade entre os próprios assalariados e introduzir novas divisões no seu interior, no que diz respeito à estabilidade do emprego e às fo0rmas de remuneração (incluindo a "poupança salarial", proposta a certas categorias). Mas o reescrever das condições de trabalho sindical não poderá esquecer o lugar que ocupa nele a luta pelo socialismo. Eis a condição necessária para solucionar a crise do sindicalismo.

Contudo, não cabe recriminar aos militantes sindicais por não terem desenvolvido sozinhos um trabalho ainda por fazer, para o qual não existe modelo. É sabido que existem militantes sindicais procurando esse modelo. Iniciarmos um esforço coletivo em torno desse tipo de projeto poderá encorajar a sua incorporação.

\section{O INDISPENSÁVEL BALANÇO DAS NOSSAS EXPERIÊNCIAS DE "CENTRALISMO DEMOCRÁTICO"}

Para os militantes de filiação marxista, um trabalho teórico que fuja à questão do balanço da experiência do "partido leninista" faria suspeitar de um grande subterfúgio político. Nós - e provavelmente setores completos da classe operária internacional - pagamos um preço político muito alto por adotar esse modelo e por termos pretendido construir o modelo de sucessivos "centro dirigente mundial" da Internacional, paralelos e/ou rivais.

Não é o único terreno em que o "programa básico do trotskismo", isto é o Programa de Transição, complementado pelos documentos dos quatro primeiros congressos da Internacional Comunista e alguns escritos de Lenin e Trotsky, teve o carimbo da "exemplaridade" quase absoluta da Revolução de Outubro. O mesmo vale para a nossa perspectiva sobre as formas de poder depois que a burguesia seja expulsa do mesmo, ou seja, nossa interpretação da "ditadura do proletariado" e nossa postura com relação à democracia durante e após da revolução. A diferença do que aconteceu com esses 
pontos, cujas posições teóricas não tivemos oportunidade de submeter às provas da vida, no que diz a respeito dos critérios de organização de o Partido revolucionário (já que o autêntico partido tinha que ser único) e do "centro dirigente mundial", não foi o mesmo. Bebemos o cálice até a borra.

Para o trotskismo a chave do fracasso situa-se nessas questões e em nenhuma outra. Confirma-se assim, da forma mais completa, a observação de Marx sobre os exemplos históricos cujas tentativas de repetição em circunstancias diferentes equivalem à imitação grosseira e patética. Penso que podem nos "perdoar" tudo (aqui o "nos" refere-se a IV Internacional de 1945 e todas as correntes que surgiram da sua ruptura), menos o fato de termos adotado e aplicado, como obedientes discípulos da Komintern, o "centralismo democrático", o modelo de "centro dirigente mundial", de "revolucionários profissionais" e todo o resto.

E foi isso tudo o que transformou colocações, que poderiam ter sido apenas orientações, em políticas erradas - cujos defeitos teriam sido revelados pela experiência, sugerindo ou impondo corretivos -, em fatos políticos destrutivos, de conseqüências irreversíveis. Não foram as posições de Michel Pablo, as que, de per se, tiveram esse caráter; foi a devastação provocada pelo primário jogo institucional baseado no mito do "centro dirigente mundial", no cargo de "secretário da Internacional" e no direito de expulsão (outorgado a ele e a maioria que o secundava) dos que discordavam das suas teses, em outros países, incluindo a França, onde os opositores eram maioria. Mais próximo no tempo e com base na minha experiência direta e pessoal de participação no Comitê Internacional da IV Internacional, no Comitê de Organização e Reconstrução da Quarta Internacional e na efêmera organização comum com a corrente morenista (o comitê Paritário que organizou a "Conferência aberta" de 1980), verifiquei que o "modelo de partido leninista" e a práxis do centralismo democrático tiveram duas conseqüências. Para as organizações que as praticaram foram um freio do pensamento e da prática política livre e criativa dos militantes, ao transformá-los de ativistas políticos em simples executantes, mulheres e homens gradativamente anulados pelo esquema em que militavam. Por outro lado, e simultaneamente, tais esquemas serviram de base para distintas variantes de poder político autocrático e oligárquico, para "mini-aparatos" marcados, em maior ou menor, grau pela corrupção financeira e moral. Chegou-se a situações em que a igualdade de direitos e deveres desaparecia, evidenciando-se que uns eram "mais iguais que outros".[12]

\section{A QUESTÃO DA "DITADURA DO PROLETARIADO"}

A exemplaridade que atribuímos a Revolução de Outubro (complementada pelo fato de nos considerarmos obrigados a assumir a herança de Trotsky "em bloco" e a defendê-la contra os stalinistas, assim como contra anarco-sindicalistas e "conselhistas"), também teve outra conseqüência: o escamoteio da questão da democracia nas fileiras da organização e na luta pela revolução. Fomos completamente indefinidos sobre as formas de organização no dia seguinte à conquista do poder. Citando a Marx e Engels, 
geralmente na leitura proposta por Lênin em O Estado e a Revolução, postulamos uma "ditadura do proletariado" expurgada das escórias policiais do stalinismo, uma ditadura "limpa", compatível com as modalidades de democracia proletária, sobre as quais tínhamos grandes indefinições. Os que colocavam reparos a isso eram tachados de "luxemburguistas", qualificação que, em algumas organizações trotskistas, era quase tão grave quanto no PCF. A forma de tratar os opositores nas declarações que apresentavam a democracia como um "engodo burguês" eram um mal presságio do que poderia ter sido o conteúdo real dessa "democracia proletária".

Não existe um modo fácil e "não violento" de enfrentar a violência do capital e a que este está sempre disposto a praticar na preservação ou reconquista da sua ditadura. Registrese, contudo, que a derrota da Revolução Russa, a partir de 1925, seu esmagamento em 1936-38, e a tomada do poder por um aparato ditatorial bárbaro, contribuiu para uma aceitação demasiado fácil do repúdio a toda forma de democracia representativa (pois a própria "democracia proletária" devia estar baseada em eleições, sendo a sua especificidade a de submeter os mandatários ao controle permanente dos mandantes) e para a formação de uma polícia política com poderes muitos amplos. Esta questão foi ignorada pela maioria das organizações trotskistas Era como se tal questão, o balanço do stalinismo - campos de concentração, fuzilamentos, processos, assassinatos, terror, ditadura contra os assalariados, genocídio (Camboja) - não repercutisse sobre elas mesmas. Como se o problema não exigisse um novo exame, ao invés de prometermos um novo Outubro sem as suas seqüelas. No novo projeto político para a revolução socialista e nos novos partidos e formas de organização que deverão ser construídos, essas questões devem ser centrais.

\section{TERCEIRA PARTE}

\section{"CABEÇALHOS" PARA UM PROJETO DE ELABORAÇÃO COLETIVA}

Este esboço de balanço, referido ao marco programático do trotskismo, somente compromete a mim, apesar de ser fruto da discussão que tivemos, ao longo de meses, no Carré Rouge. Primeiro por estar matizado por uma série de experiências organizativas especificas. Alem disso, porque é fruto da nossa avaliação, tanto do que implicou o compromisso com um programa tão profundamente como o fizemos[13], como igualmente da análise do atual momento histórico (encerramento de um período da luta de classes e transição inacabada para um período de características indefinidas). E esta tarefa é algo que cada um deve fazer por si mesmo.

Contudo, as discussões no Carré Rouge e com amigos e contatos políticos novos, porem sólidos, nos levam a crer que, ainda que alguns gritem escandalizados contra a heresia ou a traição, muitos concordam com a necessidade desse enfoque. Enforque cuja continuidade dependerá do desenvolvimento do diagnostico, através de um esforço coletivo, orientado para a "reconstrução" de uma análise que permita reduzir tanto a 
adesão a uma perspectiva socialista com base na fé, como o empirismo da nossa participação política cotidiana.

Partindo do pressuposto que estão maduras as condições subjetivas para a discussão do conteúdo desta tarefa, assumo também o risco de expor, em forma de "cabeçalhos", o tipo de "projeto de pesquisa e de elaboração políticas comuns" que imaginamos.

A tarefa não é tão simples quanto pode parecer, mas não achei outro modo de colocar os "cabeçalhos" (ou "blocos de questões") a não ser partindo das questões que devem ser respondidas por um programa inserido no marco marxista. É uma opção perigosa porque nos expõe a sarcasmos do tipo: "elaboração programática de salão" ou projeto "academicista". Contudo é uma opção difícil de evitar quando não estamos dispostos a dar às costas a um enfoque que marcou o desenvolvimento da elaboração programática da luta pelo socialismo ao longo de mais de um século e meio.

As questões colocadas aqui tem uma forte conotação de "país capitalista avançado", dum país que não sofreu diretamente a dominação da burocracia, onde os militantes não foram confrontados a sessenta anos de ditadura política e policial. Se os militantes da Rússia, Ucrânia e das antigas democracias populares podem somar-se a esta empreitada política, nosso debate ficará não apenas "enriquecido" como poderá ganhar novos rumos.

\section{Primeiro Bloco}

\section{RAZÕES PELAS QUAIS AS RELAÇÕES DE PROPRIEDADE E PRODUÇÃO CAPITALISTAS DEVEM SER SUBSTITUIIDAS E, PORTANTO, DESTRUIIDAS E NÃO REFORMADAS.}

Estas razões têm a ver, simultaneamente (e de modo tal que se esclarecem mutuamente), com

- as ameaças multiformes e incontornáveis da barbárie que a propriedade privada faz pender sobre a civilização humana, envolvendo até a criação e manipulação de seres humanos;

- a superioridade que poderiam atingir relações sociais e formas de organização política e social, fundadas - parafraseando a Marx - em que os "produtores associados assumam a organização e o uso das forças produtivas".

Toda critica do capitalismo tem, como um de seus momentos decisivos a obrigação de, no mínimo, fornecer elementos demonstrativos da viabilidade do socialismo e da sua superioridade potencial[14] Todavia, é evidente que a análise também tem que demonstrar com prioridade que o capitalismo se orienta (e já avançou consideravelmente) por um caminho que leva à barbárie: o capitalismo não é apenas neoliberalismo.

É essencial aprofundar a critica do neoliberalismo. Mas na base desta noção central do reformismo contemporâneo está a idéia de que seria possível deixar a um lado a questão da propriedade dos meios de produção, de comunicação e de troca (a moeda).[15] Falar do neoliberalismo e não do capitalismo e da propriedade privada dos meios de produção, 
comunicação e troca implica aceitar a idéia de que ainda existem, na presente configuração do capitalismo (na mundialização do capital), possibilidades de regulação do mesmo, sem alterar a propriedade privada e incluso privatizando e desnacionalizando tudo quanto se tinha exigido que fosse propriedade pública.

\section{Segundo Bloco}

\section{A CLASSE OU CLASSES PROPULSORAS DA LUTA PELA DESTRUIÇÃO DO CAPITALISMO}

Aqui colocamos a questão, ou mais exatamente, o bloco de questões mais sensíveis e objeto dos maiores tabus. Forneceremos novamente alguns elementos para ilustrar a necessidade de abordá-las. Quando se diz que o "sujeito revolucionário" já não pode ser exatamente o mesmo que na época em que Marx e Engels escreveram o Manifesto, nem o dos anos 30 ou 50, coloca-se, de fato, um conjunto de problemas muito difíceis. No Carré Rouge temos admitido e fugido disso simultaneamente, recorrendo a expressões muito ambíguas como "assalariados" ou "classe dos assalariados".[16] A questão é particularmente delicada, porque envolve algo que bem pode ser chamado "vulgata marxista", isto é, o equivalente "marxista" do catecismo da Igreja, o qual continua sendo o fundamento do comércio político da Lutte Ouvrière... e côngeneres.

Esta vulgata nos diz que a "classe operária", os "trabalhadores" ("trabalhadores produtivos") são os únicos detentores, a um só tempo, da capacidade social, da força organizacional e sobretudo de motivações suficientemente fortes para lutar pela destruição do capitalismo e a transformação socialista da sociedade. A maioria dos discursos referese, implícita ou explicitamente, à classe operária industrial (os trabalhadores que produzem a mais-valia de forma direta, que estão sujeitos mais duramente à exploração). Mais ainda, tal alusão implícita ou explicita, refere-se a essa categoria social dos países capitalistas avançados.

Ninguém, excetuando um "crente laico", pode conformar-se com essa colocação. Ela tem de ser reformulada à luz da história, das mudanças organizacionais do capitalismo (a profunda mutação das fronteiras entre "trabalho produtivo" - reputado produtor de maisvalia - e "trabalho improdutivo"; a grande desconcentração da produção; a extrema individualização das tarefas que desloca a compreensão do caráter marcadamente social do processo produtivo). Os vínculos com o primeiro bloco de questões são estreitos. Para esclarecer nossa posição devo acrescentar apenas o seguinte:

A capacidade social - técnica e política - dos que compõem o que Marx denomina "trabalhador coletivo" (enquanto sujeitos inseridos, direta ou indiretamente, na "produção"[17]) para construir e orientar outras relações sociais, está fora de discussão. Inclusive depois do desmoronamento da URSS e da enorme regressão que sofreu a idéia de socialismo, em decorrência do sinistro balanço do stalinismo, a burguesia percebe como uma ameaça aquela capacidade potencial. Em relação direta com o curso regressivo 
do capitalismo, uma das funções (menos inconsciente do que se pensa) das "reformas do ensino" é justamente a de destruir essa capacidade social, de esterelizá-la.) Não é algo dado para sempre aos revolucionários.

A questão da capacidade organizativa dos assalariados remete ao problema das relações entre "a classe em si" e as organizações e instituições que a tornam "classe para si", uma classe mobilizada, um sujeito coletivo de mudança social. Retornaremos a este ponto mais adiante.

Deve-se pensar na capacidade do capitalismo para ampliar a sua base social através da inclusão de certos segmentos da classe operária, assim como também nos mecanismos de integração dos sindicatos no Estado. Lênin abordou, há oitenta anos, um aspecto desta questão com sua análise da "aristocracia operária", que a burguesia ajudava a formar nos países imperialistas, simplesmente através dos mecanismos funcionais da dominação imperialista. O tema foi considerado tão sério que não seria mais aprofundado. O PCF e os aparatos sindicais o enterraram. Num contexto como o atual, de polarização social da riqueza e da pobreza (uma polarização sem precedentes e que continua crescendo) e de um imperialismo que renovou as suas formas de dominação mundial, é necessário saber enfrentar politicamente a questão dos traços objetivos e, em parte, subjetivos (os reflexos racistas) da "aristocracia operária" dos assalariados dos países desenvolvidos.

\section{Terceiro Bloco:}

\section{A DEMOCRACIA NA REVOLUÇÃO E NO SOCIALISMO}

Este tema tem importância estratégica. Pode-se afirmar, sem medo de errar, que sem responder a esta questão nada de essencial poderá ser feito. O socialismo, a transição de uma forma de propriedade a outra, de um tipo de estado (capitalista) a outro (socialista), faz com que a questão das liberdades, da democracia representativa sob controle permanente dos mandantes, da auto-organização das massas, esteja colocada no centro de toda reflexão séria. Temos que ser capazes de explicitar de forma convincente os vínculos entre as liberdades individuais e a organização coletiva da sociedade na revolução. Reconstruir um projeto socialista implica abordar esta questão.

É necessário, igualmente, preparar as condições para a mudança imediata das relações de produção, não apenas como relações de propriedade, mas também como relações nos lugares de trabalho. No capitalismo, é nesse âmbito, tanto como na esfera política, onde se organiza a dominação e exerce-se a violência de classe. Alem disso temos o exemplo da URSS. A importação pelo partido bolchevique das formas de organização norteamericanas, fordistas e tayloristas, foi imposta pelas circunstancias, mas não mediram e nem sequer imaginaram, provavelmente, as implicações disso para o surgimento e cristalização duma burocracia que se colocou acima do proletariado.

A violência que o capital exerceu e exercerá mais do que nunca para defender a sua 
ditadura ou reconquistá-la constitui, obviamente, um aspecto central do problema. Mas não encerra, em si, todas as respostas, pois desse modo tornaremos a percorrer o caminho que levou à ditadura stalinista. Os assalariados, desempregados, a juventude, os que vendem ou tentam vender sua força de trabalho, os pequenos camponeses, são amplamente majoritários na maior parte dos países. Esta maioria sociológica é que deve transformar-se em maioria política, em torno de um projeto, de um projeto socialista. Os assalariados não tem possibilidades de agrupar-se como classe para organizar, conjuntamente com a pequena burguesia, com as classes médias, uma coalizão, a não ser que o projeto socialista garanta como objetivo central a democracia e as liberdades.

\section{Quarto Bloco:}

\section{OS PROBLEMAS NACIONAIS E O INTERNACIONALISMO}

No decurso da longa fase da luta de classes que foi encerrada, as guerras interimperialistas e as guerras pela independência nacional dos países atrasados combinaram-se constantemente com as crises econômicas. A "transformação da guerra imperialista em guerra civil" foi o centro das condições concretas que sobre-determinaram os processos objetivos (as forças produtivas) e subjetivos (o proletariado concentrado, organizado em sindicatos e partidos) fundamentais e detonaram as situações revolucionárias.

Fora uma grande crise econômica mundial, decorrente da falência do capital fictício ligado a uma quebradeira financeira de primeira grandeza, quais seriam os mecanismos políticos aptos a oferecer uma possibilidade para a "conquista do poder", ponto de partida inexorável para uma transformação das relações de propriedade e de produção? É suficiente uma grande crise econômica?

Como dar resposta aos numerosos e graves problemas colocados pelo ressurgimento da questão nacional após a queda do stalinismo e da burocracia, na ex-URSS, na Yugoslavia e em outros países, tendo em conta que a estratégia do imperialismo é fomentar os conflitos nacionais e pulverizar o proletariado, fragmentando os estados?[18].

Como formular a unidade internacional dos assalariados e oprimidos? Para os redatores de Carre Rouge, a palavra de ordem "Estados Unidos Socialistas e Democráticos de Europa" é uma resposta parcial e provisória a essa demanda, face às agressões que os assalariados, desempregados e a juventude sofrem hoje, da parte do capital financeiro, da Comissão Européia e dos governos europeus associados a ela, e também em relação ao problema, mais importante que nunca, das relações com os EE.UU ("Europa e América"). Mas como formular essa palavra de ordem para poder projetá-la aos países da antiga URSS e das democracias populares? Estas colocações, muito distantes dos conceitos de "nação" e "soberania", são questões que ainda separam os militantes de formação trotskista daqueles originários do PCF.[19] 
Quais são as forças de classe e as formações políticas anticapitalistas e antiimperialistas hoje, na América Latina, África e Ásia? Qual é seu perfil político? Como colocar conjuntamente a questão da unidade internacional dos assalariados e oprimidos?

\section{Quinto Bloco:}

\section{OS PARTIDOS E AS FORMAS "AUTONNOMAS"; OS SINDICATOS}

Mais acima afirmamos que nenhuma das respostas dadas às questões cruciais da luta pelo socialismo podia ser considerada já definida, mesmo em suas grandes linhas, de uma vez para sempre. A questão da forma organizativa "partido", tal vez seja a mais historicamente determinada de todas.

Antes expressei minha opinião sobre os resultados do "centralismo democrático". Todavia acho que o problema das "fronteiras políticas" (luta contra o capitalismo ou tentativas de melhorá-lo) ou das "fronteiras de classe", não deixam de ser muito reais.

A questão da forma de organização "partido" não é apenas historicamente determinada, é eminentemente transitória. O que foi válido num período pode resultar obsoleto dez anos mais tarde. No contexto de um processo de desintegração/recomposição política e de mudança de "período da luta de classes", como aderir ao movimento de reconstituição de uma perspectiva revolucionária para ajudá-lo a tomar forma?

Neste plano devemos debater o fenômeno ATTAC e o movimento das correntes que se reuniram em Millau. Antigamente, uma parte teria sido classificada por nós de "esquerdismo desintegrado", mas hoje, como os classificamos?

As pessoas envolvidas diretamente na atividade sindical poderão explicar melhor do que eu de que modo a repercussão dessas questões no movimento sindical acirrou o conjunto de problemas identificados por Trotsky no seu trabalho sobre a integração dos sindicatos na fase imperialista.[20] Somente eles poderão definir a força e as fraquezas das tentativas de resistência e da renovação sindical.

\section{Concluindo}

Espero ter exposto corretamente a iniciativa de Carré Rouge. Ela parte do fato de que é inadiável "a necessidade" de uma revista do "tipo" de Carré Rouge (isto é, ajustada aos objetivos que definimos mas não conseguimos realizar) ser efetivada, realizada. Funda-se também no sentimento de que em muitos lugares os militantes manifestam de forma crescente a exigência de dispor novamente do que chamamos "visão estratégica", orientada pelo "objetivo da transformação socialista da sociedade". Em relações que serão definidas conjuntamente com organizações, correntes, coletivos e militantes individuais que aceitam a "economia geral" do processo. A ambição de Carré Rouge é transformar-se, com outras revistas, em suporte dessa empreitada coletiva. 
*Publicado originalmente em Carré Rouge, nำ 15-16, novembro 2000. Traduzido do texto em espanhol publicado em Herramienta. Revista de debate marxista, cf,. site http://www.herramienta.com.ar/; tradução de Antonio Roberto Bertelli e Ramón Peña Castro.

[1] Uma das três organizações mais significativas do trotskismo na França As outras são a Liga Comunista Revolucionária e Luta Operária (Nota de Herramienta).

[2] Omitimos alguns parágrafos referentes a atividades de interesse limitado aos leitores franceses de Carré Rouge (N. do editor)

[3]Fique claro que não usamos o termo como insulto, mas como uma caracterização política para a qual a história política do século XX deu um conteúdo preciso.

[4]Alguns pontos cruciais estão analisados no trabalho de Jean-Philippe Divès, "Elementos para un balance de la LIT y do morenismo", em Construir otro futuro. Por el relanzamiento de la revolución y el socialismo (Bueno Aires: Editorial Antídoto, 2000).

[5]A análise desse processo no seio da corrente morenista feita por Jean-Philippe Divès merece ser considerada como modelo para a história de outras correntes da IV Internacional.

[6]No caso de uma revista, isso se expressa principalmente no ecletismo de seus sumários, assim como na extrema dificuldade, senão incapacidade, de levar uma discussão para além de seu início.

[7] Essa é a expressão mais adequada que se encontra nos documentos da OCI da época, entre outras muito mais discutíveis.

[8] Salvo, tal vez, em Torino, mas sem projeção no conjunto da Itália, sem servir como modelo ou incentivar a colocação da questão do estado e do poder em Roma.

[9] No filme Reprise, apenas uma operária se revolta, mas não toda a fábrica. Os outros operários e operárias, apesar de simpatizar com a sua rebeldia não a respaldam. $E$ os delegados da CGT não são removidos.

[10] Por "longo periodo da luta de classes" entendemos um período no qual os instrumentos dessa luta estão marcados por fatos políticos e sociais que sendo variáveis, apresentam certa constância. Trata-se, neste caso dos seguintes fatos: o impacto político da Revolução de Outubro (sua exemplaridade); a existência de URSS e de um "movimento operário internacional", inicialmente controlado pessoalmente por Stalin e, a seguir, pela burocracia do kremlino e suas ramificações; o peso das indústrias manufatureiras e dos grandes serviços de base com sua organização superconcentrada que implicava fortes concentrações operários, por setores e espaços produtivos; o lugar ocupado pela luta dos povos coloniais pela sua independência na política internacional e, subseqüentemente, na vida política interna dos países imperialistas.

[11] Isto levou à redução do espaço de "assalariamento" no sentido que Bernard Friot atribui a esse termo, isto é, como conjunto de instituições que enquadram a venda da força 
de trabalho e marcam os limites da sua exploração.

10 Dito de modo implícito, com brilhantismo e ausência de afetação que lhe são próprios, tal é o sentido da Introdução de Daniel Bensaïd a um dos seus melhores livros: La discordance des temps (1995).

[12] Uma análise de processos análogos na corrente morenista foi feita por Jean-Philippe Devès no texto já mencionado.

[13] Com uma certa dose de credulidade e religiosidade.

[14] Charles-André Urly arriscou uma definição num artigo publicado por Carré Rouge n.14

[15] Na introdução indiquei que cada "cabeçalho" conterá um mínimo de elementos que os expliquem e justifiquem. Digamos, pois, e apenas com esse intuito, que a tão desqualificada caracterização do capitalismo do Programa de Transição, como um sistema no qual "as forças produtivas da humanidade deixaram de crescer", exige uma reformulação. Marcada na sua formulação pela conjuntura da crise econômica dos anos 30, julgo que uma caracterização atualizada fundamenta a necessidade de lutar pela demolição do capitalismo ainda mais do que em 1938. Depurada da sua visão catastrofista (espécie de versão trotskista da "crise final do capitalismo") de uma situação em que a burguesia "não tem mais saída", adquirem plena atualidade. Acho que caracteriza a evolução seguida pelo capitalismo, o destino que silenciosamente esse oferece a dois terços da humanidade e também as conseqüências da preservação da propriedade privada dos meios de produção nos países capitalistas avançados. É o caso da relação entre capitalismo e pesquisa cientifica. O programa de transição foi o único programa que, na perspectiva marxista, questionou o conteúdo "progressista" do "progresso técnico" no contexto da dominação imperialista. Este problema surge hoje com atualidade insólita. Tenho certeza de que não se pode dizer nada sério sobre os perigos do capitalismo e a "necessidade" do socialismo sem tratar esse problema. Se as forças produtivas continuam se desenvolvendo, as razões para aderir à luta política revolucionária contra o capitalismo resultaram bastante fracas, a despeito dos apelos morais. Alguns dirão que a realidade da exploração é razão suficiente, embora isto não seja totalmente exato. Se o capitalismo ainda se mostrar capaz de desenvolver as forcas produtivas, então a "exploração" será considerada apenas como um "custo do progresso" e, acima de tudo, resultará aceitável. Tal é o argumento básico dos novos formatos reformistas que hoje conhecemos, os quais são revigoradas por qualquer pequena melhora da conjuntura.

[16] Cyril Soler e Pierre Gantou prepararam um artigo para o n.I5 que critica seriamente tais expressões. Esse trabalho parece-me se encaixar no tipo de projeto coletivo que sugerimos aqui.

[17] Isto inclui certamente os pesquisadores. Mas os que fornecem a formação escolar dos futuros assalariados, ficam "fora da produção"?

[18] Esta questão é, por sua vez, um tema essencial que ocupa o centro do trabalho, uma questão que apenas pode aflorar no livro que Jean-Pierre Page, Tânia Noctiummes e eu escrevemos o ano retrasado sobre a guerra da OTAN na Yugoslavia.

[19] Penso particularmente em Pierre Levy, critico claro e definido de Robert Hue.

[20] Os artigos e notas de trabalho de Trotsky sobre "Os sindicatos na época imperialista", publicados por SELIO e La Brèche, são inencontráveis. Deveriam ser reeditados. 
[i] Francisco Largo Caballero, (1869-1946) "sindicalista e líder da corrente revolucionária do PSOE, chamado por seus admiradores "o Lênin espanhol". Preside o governo republicano na fase inicial da guerra antifascista espanhola (1936-39) Exilado na França, detido pela Gestapo foi enviado a um campo de concentração alemão. Morre meses após da sua liberação. (Nota do tradutor).

volta ao topo

file://C:LDocuments and Settings\Administrador\Meus documentos\Minhas Webs\NED... 11/9/2008 